\title{
AC 2010-473: AN ASSESSMENT AND DATA COLLECTION PROCESS FOR EVALUATING STUDENT PROGRESS ON "A-K" ABET EDUCATIONAL OUTCOMES
}

\section{Kathleen Ossman, University of Cincinnati}

Dr. Kathleen Ossman is an associate professor in the Electrical and Computer Engineering Technology Department at the University of Cincinnati. She earned a BSEE and MSEE from Georgia Tech in 1982 and a Ph.D. from the University of Florida in 1986. Her interests include digital signal processing and feedback control. 


\section{An Assessment and Data Collection Process for Evaluating Student Progress on “a-k” ABET Educational Outcomes}

\section{Introduction}

ABET EC2000 brought significant changes to the way engineering and engineering technology programs must assess, evaluate, improve, and document effectiveness of curriculum in order to be accredited ${ }^{1}$. This paper describes a process being used in the Electrical and Computer Engineering Technology department at University of Cincinnati to assess student progress on the "a-k" ABET Educational Outcomes. Several assessment rubrics were developed to assess students' ability in lab courses, technical knowledge and competence in project design and capstone courses, and technical communication skills including oral presentations, lab reports, and technical reports. Courses from freshmen to senior year were chosen for assessment in order to demonstrate students' development in meeting the outcomes as they progress through the program, and to identify early on any curricular areas that might require improvement. In order to make the assessment process manageable for the faculty, a java application was written that creates electronic versions of the rubrics which include the names of all the students registered in a particular course. Faculty members then simply open the electronic rubric for their course and evaluate each of the students using the assessment criteria. Aggregate data for the course is automatically created when the rubric is saved. Assessment data is collected throughout the academic year and entered into a database where benchmarks are automatically checked and assessment charts for each course are created. Faculty members meet at the start of each academic year to discuss the assessment data and to address areas where benchmarks were not met. Two complete cycles of the process have been completed. This paper will include samples of the assessment rubrics and discuss results of the assessment, changes that have been made to the curriculum as a result of the assessment, and the effect of these changes on student performance.

\section{$\underline{\text { Assessment Tools }}$}

Using a set of rubrics, students are assessed throughout the curriculum on lab performance and report writing, technical knowledge and competence, and communication skills. A selected set of course design projects, lab assignments and reports, and writing assignments both within the department and from the humanities department are assessed. Figure 1 lists the courses in the curriculum used for assessment as well as which rubrics are used in the assessment process. Courses were chosen from freshmen to senior year in order to assess student progress in meeting program outcomes and to allow early identification of any problem areas; a strong curriculum is built on good foundation courses with a focus on program outcomes. 


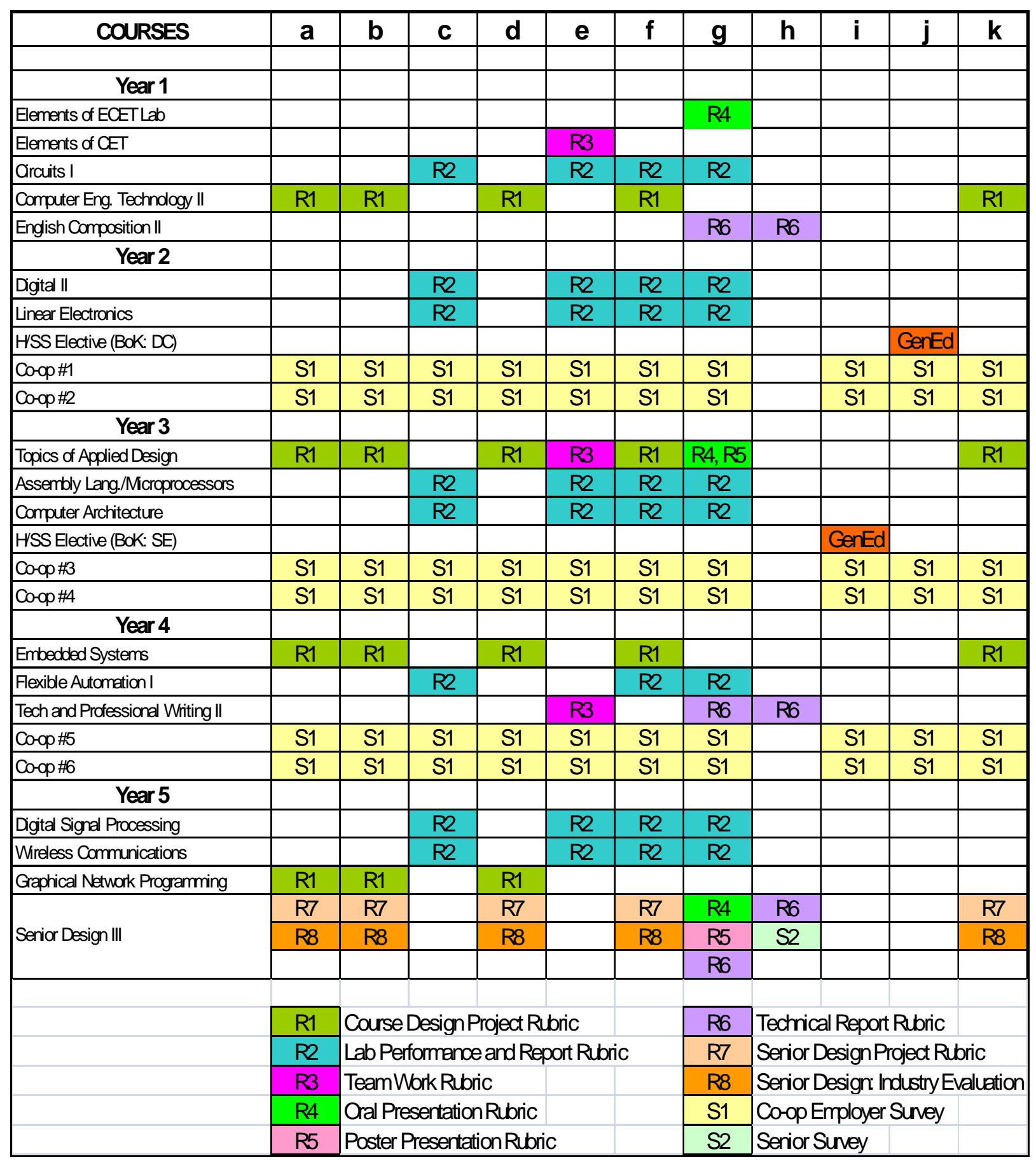

Figure 1: Course Assessment Matrix for “a-k” Program Outcomes

Several rubrics were developed by the author to assess the ABET “a-k" program outcomes. One of these rubrics, the Course Design Project rubric, is shown in Figure 2. The remaining rubrics can be found on the author's website ${ }^{2}$. The Team Work and Oral Presentation rubrics are modified versions of earlier rubrics developed by The Ohio State University, the Cabrillo Tidepool Study, and North Carolina State University ${ }^{3-5}$. 


\section{Course Design Project Rubric}

\begin{tabular}{|c|c|c|c|c|}
\hline & 1 & 2 & 3 & 4 \\
\hline CRITERIA & Unacceptable & Acceptable & Good & Exemplary \\
\hline $\begin{array}{c}\text { Technical } \\
\text { Knowledge } \\
\text { ABET-TAC.2.A } \\
\text { ABET-TAC.2.B }\end{array}$ & $\begin{array}{l}\text { Student clearly } \\
\text { lacked the pre- } \\
\text { requisite knowledge } \\
\text { in math, science and } \\
\text { technical courses } \\
\text { (both hardware and } \\
\text { software). The } \\
\text { project was either not } \\
\text { completed or was } \\
\text { completed only with } \\
\text { an unreasonable } \\
\text { amount of outside } \\
\text { assistance. }\end{array}$ & $\begin{array}{l}\text { Student demonstrated } \\
\text { an acceptable level of } \\
\text { pre-requisite } \\
\text { knowledge in math, } \\
\text { science and technical } \\
\text { courses; however, the } \\
\text { student did require } \\
\text { some technical } \\
\text { assistance from the } \\
\text { instructor or others in } \\
\text { order to complete the } \\
\text { project. }\end{array}$ & $\begin{array}{l}\text { Student readily } \\
\text { applied pre- } \\
\text { requisite } \\
\text { knowledge from } \\
\text { math, science, and } \\
\text { technical courses to } \\
\text { the project and } \\
\text { required little or no } \\
\text { outside assistance } \\
\text { to complete the } \\
\text { project. }\end{array}$ & $\begin{array}{l}\text { Student not only } \\
\text { applied knowledge } \\
\text { from pre-requisite } \\
\text { courses but also } \\
\text { applied additional } \\
\text { technical } \\
\text { knowledge gained } \\
\text { through co-op/work } \\
\text { experience or } \\
\text { through extra } \\
\text { research. }\end{array}$ \\
\hline $\begin{array}{c}\text { Technical } \\
\text { Design } \\
\text { ABET-TAC.2.B } \\
\text { ABET-TAC.2.D }\end{array}$ & $\begin{array}{l}\text { The technical skills } \\
\text { developed in pre- } \\
\text { requisite courses } \\
\text { were not evident in } \\
\text { the design of the } \\
\text { project. The project } \\
\text { was poorly designed } \\
\text { and constructed. } \\
\text { There is little or no } \\
\text { evidence of } \\
\text { programming skills, } \\
\text { design skills or } \\
\text { ability to select } \\
\text { components. One or } \\
\text { more project } \\
\text { specifications were } \\
\text { not met. }\end{array}$ & \begin{tabular}{|l|} 
Student was able to \\
apply technical skills \\
from pre-requisite \\
courses to the project \\
design. The software \\
code was acceptable \\
and included some \\
comments. Any \\
software interface \\
was reasonably easy \\
to use. Hardware \\
design and \\
component selection \\
was sufficient to meet \\
project specifications.
\end{tabular} & $\begin{array}{l}\text { Student was able to } \\
\text { apply technical } \\
\text { skills to the project } \\
\text { design. Careful } \\
\text { consideration was } \\
\text { given to design and } \\
\text { layout of hardware } \\
\text { as well as } \\
\text { component } \\
\text { selection. Software } \\
\text { was well-written } \\
\text { and commented. } \\
\text { Software } \\
\text { interface(s) were } \\
\text { well-designed and } \\
\text { user friendly. The } \\
\text { project met all } \\
\text { required } \\
\text { specifications. }\end{array}$ & $\begin{array}{l}\text { Student } \\
\text { demonstrated an } \\
\text { exemplary ability } \\
\text { to apply a variety } \\
\text { of technical tools } \\
\text { and skills to the } \\
\text { project. All sub- } \\
\text { systems and } \\
\text { hardware and } \\
\text { software interfaces } \\
\text { were well-designed } \\
\text { and fully } \\
\text { functional. } \\
\text { Component } \\
\text { selection was } \\
\text { excellent and the } \\
\text { project met all } \\
\text { specifications. } \\
\text { Code was well- } \\
\text { written and } \\
\text { commented. } \\
\end{array}$ \\
\hline $\begin{array}{c}\text { Creativity } \\
\text { and } \\
\text { Innovation } \\
\text { ABET-TAC.2.D }\end{array}$ & $\begin{array}{l}\text { Student showed no } \\
\text { evidence of creativity } \\
\text { or innovation in the } \\
\text { design of the project. }\end{array}$ & $\begin{array}{l}\text { Student showed some } \\
\text { creativity in the } \\
\text { project design. }\end{array}$ & $\begin{array}{l}\text { Student } \\
\text { demonstrated } \\
\text { innovation in the } \\
\text { design of hardware } \\
\text { or software } \\
\text { components or in } \\
\text { packaging. }\end{array}$ & $\begin{array}{l}\text { Student completed } \\
\text { a project that } \\
\text { required a lot of } \\
\text { creativity and } \\
\text { innovation in } \\
\text { design, layout, and } \\
\text { packaging. }\end{array}$ \\
\hline $\begin{array}{c}\text { Project } \\
\text { Complexity } \\
\text { ABET-TAC.2.D } \\
\text { ABET-TAC.2.F }\end{array}$ & $\begin{array}{l}\text { Student chose a } \\
\text { simple project with } \\
\text { limited scope that } \\
\text { required very little } \\
\text { creative development } \\
\text { or technical expertise. }\end{array}$ & $\begin{array}{l}\text { Student chose a } \\
\text { project with } \\
\text { acceptable scope that } \\
\text { solves a technical } \\
\text { problem and required } \\
\text { some technical } \\
\text { expertise in hardware } \\
\text { and/or software. }\end{array}$ & $\begin{array}{l}\text { Student chose a } \\
\text { complex project } \\
\text { with good technical } \\
\text { challenges that } \\
\text { required innovative } \\
\text { problem solving } \\
\text { and engineering. }\end{array}$ & $\begin{array}{l}\text { Student chose an } \\
\text { innovative, } \\
\text { challenging project } \\
\text { that required an } \\
\text { effort that exceeds } \\
\text { the normal } \\
\text { expectations for the } \\
\text { course project. }\end{array}$ \\
\hline
\end{tabular}




\begin{tabular}{|c|c|c|c|c|}
\hline $\begin{array}{l}\text { Testing and } \\
\text { Analysis } \\
\text { ABET-TAC.2.F }\end{array}$ & $\begin{array}{l}\text { Student demonstrated } \\
\text { little or no ability to } \\
\text { troubleshoot } \\
\text { hardware and/or } \\
\text { software for the } \\
\text { project. }\end{array}$ & $\begin{array}{l}\text { Student was able to } \\
\text { identify the problems } \\
\text { in hardware and/or } \\
\text { software but required } \\
\text { some assistance in } \\
\text { fixing some of the } \\
\text { problems. }\end{array}$ & $\begin{array}{l}\text { Student } \\
\text { demonstrated the } \\
\text { ability to test } \\
\text { hardware and/or } \\
\text { software in order to } \\
\text { identify technical } \\
\text { problems, and was } \\
\text { able to solve any } \\
\text { problems with little } \\
\text { or no assistance. }\end{array}$ & $\begin{array}{l}\text { Student developed } \\
\text { a good systematic } \\
\text { procedure for } \\
\text { testing hardware } \\
\text { and/or software that } \\
\text { allowed for quick } \\
\text { identification of } \\
\text { technical problems. } \\
\text { Student was very } \\
\text { good at analyzing } \\
\text { and quickly solving } \\
\text { all technical } \\
\text { problems. }\end{array}$ \\
\hline $\begin{array}{c}\text { Project } \\
\text { Management } \\
\text { ABET-TAC.2.K } \\
\text { ABET-TAC.8.B }\end{array}$ & $\begin{array}{l}\text { Student failed to meet } \\
\text { most of the deadlines } \\
\text { for the project and } \\
\text { the project was not } \\
\text { completed in time. }\end{array}$ & $\begin{array}{l}\text { Student fell behind } \\
\text { on the project } \\
\text { schedule but was able } \\
\text { to catch up and get } \\
\text { the project working at } \\
\text { an acceptable level } \\
\text { by the final due date. }\end{array}$ & $\begin{array}{l}\text { Student did a good } \\
\text { job of following } \\
\text { the schedule and } \\
\text { completed the } \\
\text { project by the final } \\
\text { due date. }\end{array}$ & $\begin{array}{l}\text { Student worked } \\
\text { ahead of schedule } \\
\text { to complete the } \\
\text { project early } \\
\text { leaving plenty of } \\
\text { time for project } \\
\text { improvement. }\end{array}$ \\
\hline $\begin{array}{c}\text { Aesthetic } \\
\text { Design }\end{array}$ & $\begin{array}{l}\text { Student did a sloppy } \\
\text { job of wiring and } \\
\text { soldering hardware } \\
\text { and/or writing the } \\
\text { software code for the } \\
\text { project. Little or no } \\
\text { consideration was } \\
\text { given to packaging or } \\
\text { appearance. }\end{array}$ & $\begin{array}{l}\text { Wiring and soldering } \\
\text { was neat and some } \\
\text { thought was given to } \\
\text { the visual design of } \\
\text { any software } \\
\text { interface. The project } \\
\text { appears neat and } \\
\text { organized but } \\
\text { packaging was not a } \\
\text { consideration. }\end{array}$ & $\begin{array}{l}\text { The project was } \\
\text { visually appealing } \\
\text { with some thought } \\
\text { given to packaging } \\
\text { and PWB design. } \\
\text { Software } \\
\text { interface(s) were } \\
\text { clearly designed } \\
\text { with appearance } \\
\text { and ease of use in } \\
\text { mind. }\end{array}$ & $\begin{array}{l}\text { Student went above } \\
\text { and beyond to } \\
\text { package the project } \\
\text { as a finished } \\
\text { product. }\end{array}$ \\
\hline
\end{tabular}

Figure 2: Course Design Project Rubric

Using the rubrics, a faculty member teaching one of the courses chosen for assessment rates each student enrolled in the course on several criteria as Unacceptable, Acceptable, Good, or Exemplary. The rubrics are carefully worded to clearly describe the competencies expected for each of these ratings. These descriptions make the expectations of our program very clear and help ensure consistency among the faculty when rating students. The rubrics are not tied to the specific content in a course and can therefore be used in multiple courses throughout the curriculum. Using the same rubric from freshmen to senior year allows us to measure student development as they progress through the curriculum. Each rubric is also designed to measure several of the ABET “a-k" educational outcomes with each performance criterion in a rubric clearly tied to one or more of these outcomes.

In addition to course assessment by faculty, the department uses two assessment tools which provide feedback from practicing engineers in industry. Students are assessed by their co-op employers (co-op is mandatory) using a survey developed by Professional Practice at University of Cincinnati in which employers rate the co-op students on abilities tied closely to the ABET "a$\mathrm{k}$ ” outcomes. The senior capstone projects are evaluated by members of our industrial advisory 
board and include ratings on technical knowledge and design, project aesthetics and creativity, and oral presentation skills.

\section{Faculty Buy-in}

A key factor in the success of an assessment procedure is making the process non-arduous in order to guarantee the participation of busy engineering faculty who most likely don't place assessment at the top of their priority list. To make the assessment process simple, two java applications were written by a former faculty member, Brian Resnick ${ }^{6}$. The first java application takes a class list downloaded from Blackboard and pairs it with a selected rubric to create an electronic rubric for faculty to fill out. Faculty use the second java application to open the electronic rubric. Screen shots of the rubric are shown in Figures 3 and 4. Faculty have the option to rate all the students on each performance criterion as shown in Figure 3 or rate each student on all the performance criteria as shown in Figure 4. The worded description of each performance criterion is included for easy reference. Initially, all tabs down the left side of the rubric are red. As faculty complete assessment by simply clicking on the radio buttons, the tabs turn green to indicate a category or individual student assessment has been completed. Of course Student 1 , Student 2, etc. are replaced by the names of the students actually enrolled in the course.

\section{Electronic Assessment Rubric for Course Design Project}

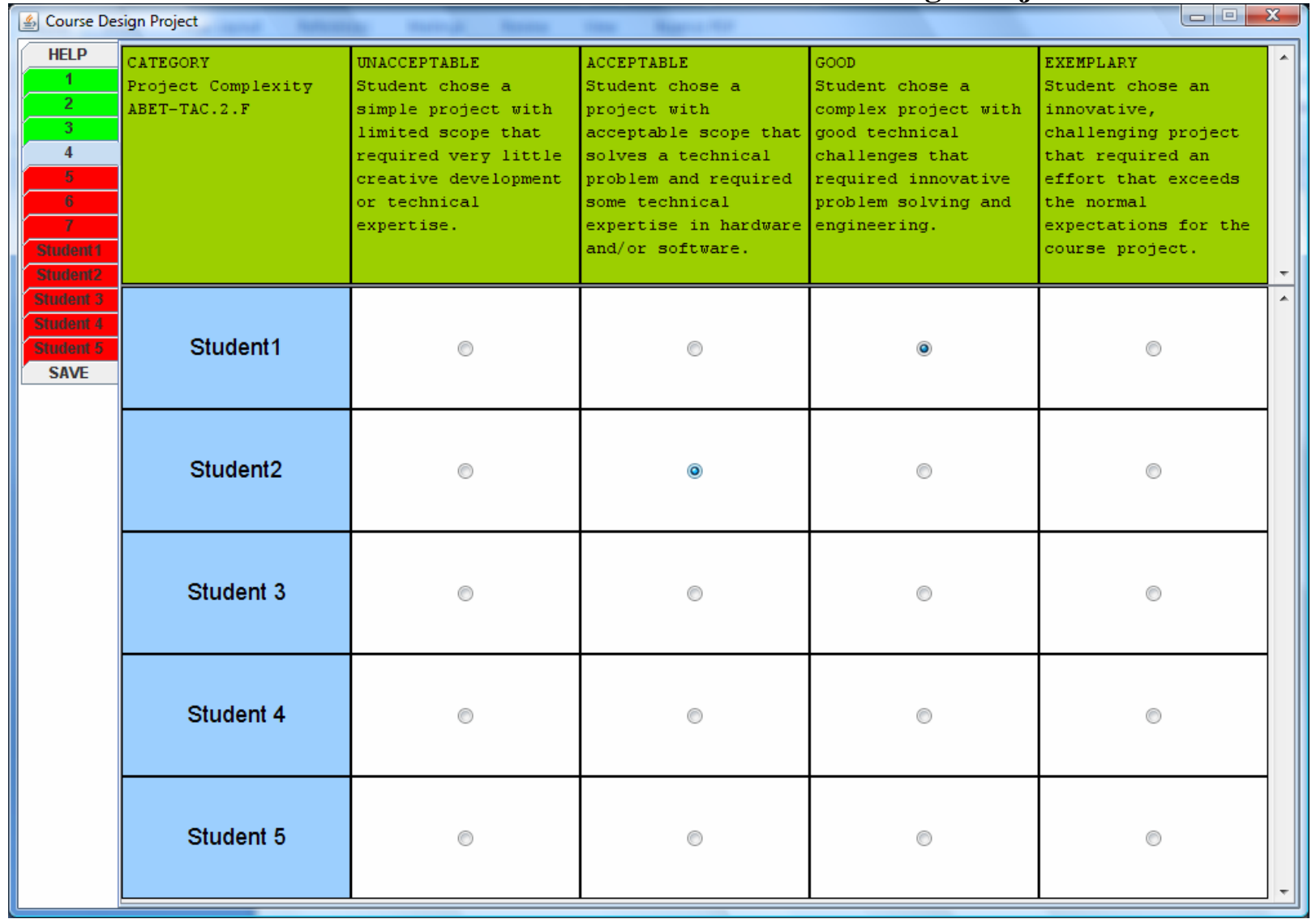

Figure 3: Option One - Assessing Criteria by Criteria 
Electronic Assessment Rubric for Course Design Project

\begin{tabular}{|c|c|c|c|c|c|}
\hline HELP & CATEGORY & UnACCPPAasle & ACCEPTABLE & 6000 & DEMPLLARY \\
\hline$\frac{3}{4}$ & Technical Knowledge & 0 & - & $\odot$ & 0 \\
\hline $\begin{array}{l}\text { Student } \\
\text { Student2 }\end{array}$ & Technical Design & 0 & 0 & • & ○ \\
\hline $\begin{array}{l}\text { Sthoumt } \\
\text { SAVE } \\
\end{array}$ & Creativity and Innovation & 0 & - & $\theta$ & 0 \\
\hline & Project Complexity & 0 & - & ○ & 0 \\
\hline & Testing and Analysis & 0 & 0 & ๑ & 0 \\
\hline & Project Management & 0 & 0 & 0 & ○ \\
\hline & Aesthetic Design & 0 & 0 & ๑ & 0 \\
\hline & \multicolumn{5}{|c|}{\begin{tabular}{|l|l|} 
Exclude & Reset \\
\end{tabular}} \\
\hline
\end{tabular}

Figure 4: Option Two - Assessing Student by Student

Once a faculty member completes the assessment rubric, he or she returns the file to the department's assessment coordinator. The file can be opened using excel and contains not only the instructor's assessment of each individual student but also a table of aggregate data displaying the number of students ranked as Unacceptable, Acceptable, Good, or Exemplary for each of the performance criteria. The aggregate data is copied into an excel assessment database developed by the author which automatically checks the assessment data against the performance benchmarks developed by the department. At the start of each academic year, the co-op employer survey data from the previous year is also added to the assessment database and automatically measured against performance benchmarks. The database creates an easy to view report of the assessment data with tables and graphs applicable to each of the "a-k" program outcomes clearly indicating which benchmarks were met and which benchmarks were missed. Assessment data is circulated to every member of the department then all members of the department faculty meet to discuss areas for improvement. It is important to note that although faculty and co-op employers are assessing individual students, only the aggregate data is reviewed by department faculty and presented to ABET reviewers, thus protecting the privacy of all students in the program. A summary of the assessment data, along with the proposed changes to the curriculum driven by the assessment data, are presented for discussion to the ECET industrial advisory board at the annual fall meeting. 


\section{Curriculum Changes Driven by Assessment Results}

The assessment process began in autumn 2007 and two years of assessment data has been collected and evaluated by department faculty. Evaluation of the data from the first year (20072008) identified areas in which the program needed improvement; specifically: project management, creativity, aesthetic design, and, for lower level students, presenting and analyzing data and writing effective technical conclusions. Several changes were made in the second year to address these areas. Second year assessment data (2008-2009) indicated that some of the changes were very effective while others were not.

Project management, creativity, and aesthetic design are measured through course design projects and the senior capstone project. Faculty felt that lack of attention to aesthetic design was likely a result of poor management skills; that is, students completing their projects at the very last possible moment. To improve project management in course design projects, faculty decided to implement intermediate deadlines for various stages of the project. For the year-long senior capstone project, a mandatory demonstration day was added to the end of winter quarter and most faculty advisors required weekly or bi-weekly update meetings throughout the winter quarter. To boost creativity in course design projects, some projects were re-designed to allow more variety and creativity was rewarded. For the year-long senior capstone project, brainstorming project sessions were added at the beginning of the autumn quarter. Students presented their project ideas to faculty and to the other seniors and received good suggestions on how to expand the project and make it more innovative.

Assessment data from the second year (2008-2009) indicates that the changes outlined to improve project management, creativity, and aesthetic design were indeed effective. The most dramatic improvement was seen in the senior capstone projects. Table 1 shows the faculty advisor assessment of capstone projects in spring 2008 and in spring 2009; while Table 2 shows the industry advisors assessment of capstone projects in the same two years. The spring 2009 assessment data clearly indicates that the changes made in senior design resulted in improved performance in the targeted areas of project management, creativity, and aesthetic design. Note that industry advisors cannot assess project management skills since they only see completed projects and have no earlier interaction with students during the senior year. However, they do assess project complexity which should be a reasonably good indicator of management skills so the complexity assessment is included in Table 2.

Table 1: Faculty Evaluation of Senior Capstone Projects

\begin{tabular}{|c|c|c|c|c|c|c|c|c|c|c|}
\hline & \multicolumn{4}{|c|}{$\mathbf{2 0 0 7 - 2 0 0 8}$} & \multicolumn{5}{c|}{$\mathbf{2 0 0 8 - 2 0 0 9}$} \\
\hline & Unacc. & Acc. & Good & Exc. & Avg & Unacc. & Acc. & Good & Exc. & Avg \\
\hline $\begin{array}{c}\text { Project } \\
\text { Management }\end{array}$ & $16 \%$ & $37 \%$ & $47 \%$ & $0 \%$ & 2.3 & $0 \%$ & $36 \%$ & $45 \%$ & $18 \%$ & 2.8 \\
\hline Creativity & $5 \%$ & $53 \%$ & $21 \%$ & $21 \%$ & 2.6 & $0 \%$ & $14 \%$ & $41 \%$ & $45 \%$ & 3.3 \\
\hline $\begin{array}{c}\text { Aesthetic } \\
\text { Design }\end{array}$ & $21 \%$ & $11 \%$ & $47 \%$ & $21 \%$ & 2.7 & $9 \%$ & $14 \%$ & $41 \%$ & $36 \%$ & 3.0 \\
\hline
\end{tabular}


Table 2: Industrial Advisor Evaluation of Senior Capstone Projects

\begin{tabular}{|c|c|c|c|c|c|c|c|c|c|c|}
\hline & \multicolumn{5}{|c|}{ 2007-2008 } & \multicolumn{5}{|c|}{ 2008-2009 } \\
\hline & Unacc. & Acc. & Good & Exc. & Avg & Unacc. & Acc. & Good & Exc. & Avg \\
\hline $\begin{array}{c}\text { Project } \\
\text { Complexity }\end{array}$ & $0 \%$ & $45 \%$ & $50 \%$ & $5 \%$ & 2.6 & $0 \%$ & $29 \%$ & $67 \%$ & $4 \%$ & 2.8 \\
\hline Creativity & $0 \%$ & $32 \%$ & $55 \%$ & $14 \%$ & 2.8 & $0 \%$ & $13 \%$ & $83 \%$ & $4 \%$ & 2.9 \\
\hline $\begin{array}{l}\text { Aesthetic } \\
\text { Design }\end{array}$ & $0 \%$ & $41 \%$ & $55 \%$ & $5 \%$ & 2.6 & $0 \%$ & $21 \%$ & $67 \%$ & $13 \%$ & 2.9 \\
\hline
\end{tabular}

Assessment data from the first and second year indicated that the upper level students are very effective in lab performance, data analysis and presentation, and technical writing. However, the lower level students ( $1^{\text {st }}$ and $2^{\text {nd }}$ year) struggle with writing effective technical conclusions and with presentation and analysis of lab data.

In autumn 2008, first-quarter freshmen were introduced to equation editor in Word and the chart wizard in Excel and definite improvement was seen in their ability to produce charts and tables. However, an ability to talk about data in technical terms and discuss the objectives of a lab and how those objectives were achieved is still a problem for many first and second year students. In Elements of EET (a course taken by all first quarter freshman), unacceptable technical conclusions were returned and students were required to re-write them. The second attempts were in most cases significantly better than the first attempts. However, these freshmen still didn't seem to take writing seriously enough to carry what they learned in the first quarter to lab courses in subsequent quarters.

For the current academic year (2009-2010), department faculty teaching all freshman courses will be consistent in requiring quality technical conclusions and effective data analysis. The practice of rejecting lab reports with unacceptable technical conclusions will be extended to the Circuits I and II courses in the winter and spring quarters.

\section{$\underline{\text { Conclusion }}$}

A process for assessing the ABET “a-k” outcomes using a set of well-designed rubrics, co-op employer data, and input from industrial advisors has been developed. The assessment process was designed to be relatively simple for faculty members to complete and a database was created to simplify the task of data collection and presentation for the assessment coordinator. Data from the last two years indicates that the process appears to be effective in identification of problem areas and in determining and appropriately documenting whether or not program changes are effective in improving the program.

\section{Bibliography}

1. Engineering Change: A Study of the Impact of EC2000 (Executive Summary) http://www.abet.org/Linked\%20Documents-UPDATE/White\%20Papers/Engineering\%20Change.pdf 
2. http://homepages.uc.edu/ ossmanka

3. http://www.cse.ohio-state.edu/ neelam/abet/DIRASSMNT/teamworkRubric.html

4. http://edweb.sdsu.edu/triton/tidepoolunit/Rubrics/collrubric.html

5. http://www.ncsu.edu/midlink/rub.pres.html

6. Brian Resnick, Director, Emerging Technologies, Intelligrated, Inc., Cincinnati, OH. 